\title{
Belief and unbelief: Two sides of a coin
}

\author{
Grace Davie
}

In what follows I build on to previous writing relating to the nature of religion (including religious belief) in modern Europe and the factors that must be taken into account if this is to be properly understood (Davie 1994, 2000, 2002, 2006). These factors are:

- the cultural heritage of Europe;

- the 'old' model of a moderately dominant state church which operates like a public utility;

- a 'newer' model which takes the form of a growing market in religion;

- the arrival into Europe of new groups of people both Christian and other;

- an increasingly articulate secular lobby.

The first point to grasp is that all five exist alongside each other and that they push and pull in different directions. The second point provides the focus for this article: namely that exactly the same factors that account for the nature of religious belief in European society are equally present in unbelief. I will take each of them in turn in order to illustrate this point.

\section{Cultural heritage}

Both religious belief and its obverse unbelief are part of culture: they do not exist in a vacuum. In the European case, both have been formed by the Judaeo-Christian tradition which has been part of our heritage for two millennia and - whether we like it or not - has defined the categories in which we think. It follows that those who reject religious 
belief in this part of the world are rejecting a culturally determined version of this. Many of them, moreover (articulate atheists included), know a great deal about the God in which they do not believe. In Europe, this is a Christian God. That is not to say that the JudaeoChristian tradition is the only formative factor to take into account in the evolution of Europe. Greek rationalism and Roman organisation are equally significant. The first of these becomes a crucial element in the markedly secular European Enlightenment.

\section{The old model: religion as a public utility}

The Constantinian settlement in the fourth century ensured that the dominant forms of European religion have been embedded in territory; first in the form of empire and then in the form of the nation state. Since the Reformation, the major expression of religious life in Europe can be found in a state or legally-privileged church - recognising that the specific theology associated with this institution varies in different parts of the continent. Historically these churches were powerful institutions able to coerce unwilling populations over which they had authority - they could be, indeed they often were, excluding and exclusive. Happily that power no longer exists; instead there has been a distinctive mutation. In the liberal democracies of modern Europe, state churches operate as public utilities: they are there at the point of need for those who live in the country in question - an inclusiveness repeated at diocesan and parish level. These are territorially-defined institutions which work on a model of opting out rather than opting in. Unless they declare otherwise - which they are entirely free to do - all those who live in a designated area 'belong' to the church. For this reason, such churches encompass a huge range of belief and unbelief.

The ways in which these relationships are put into practice vary considerably in different parts of Europe. France and Norway offer instructive examples in terms of the argument of this article, not only because of the nature of their respective churches but because the communities of unbelief in each country form mirror images of these institutions. In France, for example, a hegemonic Catholic Church proscribed the possibility of religious alternatives considerably longer than elsewhere. Religious persecution persisted right through the 
seventeenth century, culminating in the Revocation of the Edict of Nantes in 1685. De facto toleration began to emerge in the following century. De jure toleration for the much reduced Protestant and Jewish communities came just ahead of the Revolution in 1787.

An important consequence of this situation lies in the fact that the definitive challenge to the Catholic Church came eventually from a self-consciously secular state rather than a religious minority - a 'battle' which culminated in the establishment of the Third Republic in 1870. The French state moreover claimed for itself the moral qualities previously associated with the Catholic Church, underpinning its authority with a carefully articulated secular philosophy. Laïcité is difficult to translate into English but means effectively the absence of religion in the public square - it is an ideological as much as a descriptive term. It can however be interpreted variously: at one end of the spectrum it is a relatively neutral concept; at the other it denotes a militant, anti-clerical stance - at times tipping over into a mistrust of all religion. Whatever the case it is quintessentially French and derives from a very particular religious past.

Norway is different. Here the community of humanists (a surprisingly large proportion of the population as a whole) reflects the characteristics of the majority church - that is a Lutheran state church supported by church tax. ${ }^{1}$ The relatively wealthy Norwegian Humanist Association is similarly financed - paradoxically in the sense that the philosophical views embraced by this organisation lead it to oppose rather than support the notion of a state church. A second similarity can be found in the efforts made by Norwegian humanists to establish equivalent liturgies to the Lutheran Church, notably those associated with birth, adolescence (coming of age) and death. This is necessary in a population where significant numbers of individuals continue to seek the services of the church at the turning points in life. Norwegian humanists, finally, have forthright views - there can be no doubt about this - but they are expressed in typically Norwegian ways. They are very different in tone and content from their rather more aggressive French equivalents.

In parenthesis, an interesting comparison can be made with the United States. Unbelief - or more accurately, no-religion ${ }^{2}$ - is growing in America, but from a very low base; the constituency remains 
considerably smaller than it is in Europe. Why? There are many reasons for this difference, but among them it is worth reflecting on the absence of a dominant church. There is, instead, an almost infinite variety of denominations from which the believer can choose, chopping and changing at will. But if there is no dominant church against which to react, how will the 'opposition' (the secular) understand itself? One point is clear: many Americans observe with disquiet the growing dominance of what is known as the New Christian Right, the more so given its evident political influence. It is also clear that the culture wars of modern America show no sign of diminishing. If anything, the reverse is true: secular liberals continue to oppose moral conservatives on a wide range of issues. Resistance to the NCR, however, is as likely to be found in the different currents of Christianity as it is in secularism as such - there are plenty of alternatives on offer. A second point follows from this: in the United States there is not only no state church, but no notion of the state in the sense that this is understood in Europe, and - still less - any idea that the state might claim for itself the moral authority normally associated with a church. Secularists, just like churches, in the United States must discover alternative ways to sustain themselves.

\section{An incipient market in religion}

All over Europe, however, the residue of the state church (the public utility) is gradually - and in many cases only very partially - giving way to something different: a growing market in religion, in which a wide range of organisations compete for the attention of a public that becomes increasingly aware of the religious or spiritual 'goods' on offer. They choose accordingly; in other words they opt in, not out. The important point to grasp is that these choices vary in nature, and that they include unbelief as well as belief - a very different situation from that outlined above. It is equally clear that there are gainers and losers in this situation on both sides of the equation, an inevitable effect of the market. We need to ask therefore what kinds of belief and unbelief are proving attractive in late modernity?

In terms of unbelief, an interesting question arises. I have argued elsewhere (Davie 2006) that the forms of religious organisation and 
associated belief that are gaining in market terms are those that are best described as experiential rather than the purely cerebral, noting that this was not what social scientists of religion who were active in the mid post-war decades had anticipated. Such scholars had assumed that the forms of religion that were most 'rational' (i.e. those which engaged most easily with the modern world) would be those most likely to flourish in the late twentieth century. Such is not the case, a point on which the evidence is unequivocal. ${ }^{3}$ The forms of religion that are currently prospering are on the whole conservative in their theological outlook, frequently combining this with a softer, experiential 'style'. It is worth asking whether the same is true of unbelief, an approach that leads in turn to further questions. What, for example, might experiential atheism look like and how might this be expressed? The answer is not immediately clear. At one level it is true that atheists, just like believers, respond to what are called 'peak experiences'. At another, the fact that the criticisms that unbelievers direct towards religion are so often based on the primacy of reason must surely favour the rational over the expressive. A third point is worth pondering. Believers are very often exposed to the experiential in the course of worship. It is built into the liturgy and becomes an essentially shared activity. Is there an equivalent for unbelievers who - by definition - do not engage in such activities?

\section{New arrivals}

Returning to the central theme of this paper, it is quite clear that the old and the new models of religion exist side by side in twenty-first century Europe and will continue to do so for the foreseeable future (this is not a free market in the American sense). And in many ways the system works well: each economy fills the gaps left by the other. Those who wish to choose do so amongst an ever-growing range of options; those who have no interest in choosing rely on the public utility. That, however, is not the whole story, given that new groups of people are arriving into Europe all the time, bringing with them new ways of being religious - thus extending the range of choice still further. Not all of these people are Christians, though many are. In Britain, for example, Afro-Caribbean churches have captured a 
significant slice of the market and display not only experiential but exuberant styles of worship.

Even more important for the argument presented here are the other-faith populations - notably, but not exclusively, the Muslim communities. Not because they are particularly numerous (they are not), but because they are challenging the deeply held conviction among the great majority of Europeans that belief is a private matter. The reason is simple enough. Islam forms part of a very different cultural heritage in which religion is not a discrete activity as it has become in the West, but a way of life. In the ummah, the religious and the secular are inseparable from each other and both, it follows, are present in the public sphere. But how does this practice operate beyond the ummah - that is, in those parts of the world where Muslims live in diaspora?

It is at this point that the debate about both belief and unbelief in Europe becomes noticeably more intense. In many ways, the strength of the reactions is hardly surprising, given - once again the expectations of an earlier generation of scholars. In the 1960s and 1970s, social scientists were very largely agreed that the public significance of religion would be likely to decline as the century drew to a close, but that private belief might endure for longer in the private sphere. The former point is admirably illustrated by the work of Bryan Wilson who went so far as to define secularisation as the decline in the social significance of religion in modern societies (Wilson 1969). The latter found expression in the phrase for which I am largely responsible: 'believing without belonging' (Davie 1994). Paradoxically, exactly the reverse has happened: private belief (unsustained by any kind of institution) is dwindling fast, especially in northern Europe, but religion as such has re-entered the public sphere. Dramatically so at times.

A whole series of episodes illustrate this point. In the 1990s critically important debates concerning the place of religion in modern societies took place in Britain and France. In Britain, the Rushdie controversy raised crucial issues about the freedom of speech and its obvious counterpart - the freedom of belief. Pushed to the limit, they inevitably collide. In France the affaire $d u$ foulard provided a similar catalyst, focusing this time on what could and could not be 
worn in 'public' institutions, notably the state and the school system. In the new millennium, the Dutch, Danish, Swiss and Swedish cases have moved centre stage, each of them triggered by a specific and seemingly irresolvable event or issue. All of these episodes moreover are inextricably linked with what is happening worldwide - a scenario in which 1979 emerges as a key date. It was at this moment that Shah and his family fled from Iran, displaced by a regime motivated by conservative readings of Islam. It was, of course, the Iranian ayatollah who pronounced the fatwa threatening the life of Salman Rushdie - a turning point in the controversy as a whole.

\section{Secular reactions}

I will argue that it is the reassertion of religion in the public sphere which has provoked a considerably more hostile reaction among certain kinds of secularist - a group who can be relatively relaxed about the private convictions of their fellow citizens, but who resist strongly the encroachments of religion in public life. Dominant among these people are the new atheists, who in many ways adopt the characteristics of the forms of religion that they most dislike. The argument runs as follows and rests on a particular understanding of fundamentalism, defining this as 'a world view that highlights specific essential "truths" of traditional faiths and applies them with earnestness and fervor to twentieth-century realities' (Kaplan 1992, 5). Both parts of this definition are crucial - the existence of essential truths and their application to twentieth-century realities. For this reason, the word fundamentalism should not be used to describe the traditional elements of religions that have been left untouched by the modern world, nor does it mean the creation of entirely new ideas. It involves the re-affirming of essential truths within a situation that has been disturbed, either by new forms of scholarship or by the pressures of an expanding global economy and the effects that this has on social, political or ideological life.

Can this approach be applied to secular as well as religious worldviews? I believe this to be the case (Davie 2007, 195-99). Such worldviews, moreover, include secularism - for the following reasons. In many ways, secularism (rightly or wrongly) has become 
the assumed ideology of modern Europe: both scholars and activists expected a future that was more rather than less secular, even if belief endured in the private sphere. The return of religion to public discussion is therefore anomalous; it undermines the status quo and becomes a 'problem' to be resolved. One reaction (among many others) has been a regrouping amongst secularists to re-state and re-affirm the essential truths of their position: it is this that constitutes 'new' atheism. Its nature - moreover - is strikingly similar to the notion of religious fundamentalism as this set out above and as it is developed in the 'Fundamentalism Project' (Marty and Appleby 1991). A core feature of the latter's work is an ideal-type of fundamentalism. Not every feature of the ideal-type is present in new atheism; without doubt, however, it is essentially re-active in its nature and is dominated by an elite who think in black and white terms, and who aim in their public announcements to disturb, and indeed to shock. Such an approach is helpful in that it demonstrates very clearly why the advent of new atheism coincides with the return of religion to the public sphere. This is not a zero sum game: each encourages the other.

That said, it is equally important to remember that not all unbelievers are sympathetic either to the ideas or to the methods of new atheists. Indeed, the views of unbelievers - like the adherents of all world faiths - lie along a spectrum. At one end their ideas are barely distinguishable from those of 'believers' - particularly the ones who remain distanced from institutional religion; at the other can be found a sharpness of expression that borders on aggression. It is the latter that displays at times the characteristics of fundamentalism.

\section{Concluding remarks}

One further point concludes this article. It concerns what has become known as European exceptionalism (Davie 2002). The essential point is easily summarised: Europeans are gradually beginning to realise that Europe is secular not because it is modern, but because it is European. For this reason, explanations for the relative secularity of Europe must be sought in the specificities of European history, not in an oversimple elision of the secular and the modern. Secularisation, in other words, is not an inevitable part of the modernisation story;

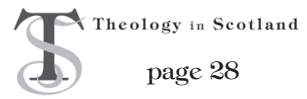


it occurs in some parts of the modern world but not in others. It is also true that some Europeans welcome this insight, others are disconcerted by it. Among the former are those who use this argument to resist the encroachments of new forms of religion from outside; among the latter are those who simply assumed that what Europe did today in terms of religion or indeed secularity, everyone else would do tomorrow. Such is not the case. Indeed quite the opposite is true: the great majority of the modern world remains as "furiously religious as it ever was' (Berger 1999, 2).

The crucial point to recall with respect to the argument presented here is that European secularism or unbelief - in just the same way as European religion or belief - is not for export. Both must be seen as an integral part of the evolution of Europe (a relatively restricted part of the world) and must be understood in these terms.

\section{Notes}

1 It is important to note that the legal and financial position of the Church of Norway is currently under review.

2 This section of the population is known as the 'nones', in the sense that they do not belong to any church. A significant number of them, however, continue to believe in God (Pew Forum 2008).

3 In the 1960s, for example, the future seemed bright for various forms of liberal Protestantism; some forty to fifty years later, there are two rather different success stories: charismatic evangelical churches both inside and outside the mainstream and - less intuitively - cathedrals or city-centre churches (Davie 2006).

\section{Bibliography}

Berger, Peter L., ed. 1999. The Desecularization of the World: Resurgent Religion and World Politics. Grand Rapids, Mich.: Ethics and Policy Centre; Wm. B. Eerdmans Publishing Co. 
Davie, Grace. 1994. Religion in Britain Since 1945: Believing Without Belonging. Oxford: Blackwell.

-2000. Religion in Modern Europe: A Memory Mutates. Oxford: Oxford University Press.

- 2002. Europe: The Exceptional Case: Parameters of Faith in the Modern World. London: Darton, Longman \& Todd.

-2006. "Religion in Europe in the 21st Century: The Factors to Take Into Account." European Journal of Sociology 47: 271-96.

. 2007. The Sociology of Religion. London: Sage.

Kaplan, Lawrence, ed. 1992. Fundamentalism in Comparative Perspective. Amherst, Mass.: University of Massachusetts Press.

Marty, Martin E. and R. Scott Appleby, eds. 1991. Fundamentalisms Observed. Chicago: University of Chicago Press.

Pew Forum on Religion in Public Life 2008. US Religious Landscape Survey. http://religions.pewforum.org/reports (accessed on 30.4.2012).

Wilson, Bryan R., 1969. Religion in Secular Society: A Sociological Comment. Harmondsworth: Penguin.

This paper originally appeared in Approaching Religion, vol 2, no 1 (2012), published by the Donner Institute. It is reproduced here with the kind permission of the editor. 